\title{
Environmentální výchova z pohledu informační vědy
}

\section{Jan Činčera}

Envigogika 2007/II/2 - Recenzované články/ Reviewed Papers

Publikováno/Published 31. 08. 2007

DOI: http://dx.doi.org/10.14712/18023061.17

\begin{abstract}
Abstrakt:
Článek analyzuje vybrané otázky metodiky a cílů environmentální výchovy z pohledu informačních a komunikačních teorií.
\end{abstract}

\section{Klíčová slova:}

Teorie informace, komunikační teorie, metodika environmentální výchovy, autenticita, legitimita, konstruktivizmus

\section{Abstract:}

The goal of the article is to analyze some questions of environmental education from the point of view of information science. It starts with a short definition of information science and then it clearly clarifies the main areas of information and communication theories.

It compares two different concepts of information: as universalia in rebus and post res. It shows that environmental education works with both of these types of information, that symbolic information plays a more important role for some activities and 'structural' information for others.

In the second part it differentiates between mathematical and hermeneutical communication theories and clarifies the connection between communication theories and educational models. In the example of a selected environmental education program it analyzes how the program can be shaped by constructivist educational models.

In the last part the article a discussion opens on the vertical and horizontal modus of communication. This discussion is connected with the question of authenticity of communication and legitimacy of environmental education. It touches on the phenomenological views of human authenticity, as an active being open to the being. The question of authenticity is linked to areas of environmental education, which is asked to be open, dialogic and authentic.

\section{Key words:}

Information theory, communication theory, methodology of environmental education, authenticity, legitimacy, constructivism 


\section{Úvod}

Zatímco obsah informační vědy si lidé ve dnešní době intuitivně spojují s databázemi, internetem a virtualitou, environmentální výchova se vztahuje ke světu pod našima nohama. Svým způsobem těžko najít disciplíny, jejichž záběr je tak rozdílný. Cílem článku je poukázat na paralely, které mezi oběma disciplínami je přes tuto rozdílnost možné nalézt. Porozumění některým otázkám informační vědy nám mưže pomoci $v$ lepším porozumění metodice environmentální výchovy, dokonce i v náhledu na její smysl a podstatu.

Podle T.C. Bearbona (Curras, 1966) se informační věda zabývá „celým procesem informace". Můžeme rozlišit čtyři hlavní předměty jejího zájmu: informační teorii, komunikační teorii, teorii médií a informační etiku, která může být dále dělena na mikroetiku (řešení morálních dilemat v informační praxi) a makroetiku (morální analýzu společenských dopadů informační praxe) (Capurro, 2001a; Capurro, 2001b). V následujícím textu se budeme zabývat prvními dvěma oblastmi.

Pojmy „informace" a "komunikace” jsou široce skloňovány ve všech pedagogických přístupech a tedy i v environmentální výchově. Jaký je ale význam pojmu „informace"? Jaká je podstata „komunikace"? A jakým způsobem může porozumění oběma pojmům ovlivnit či dokonce zkvalitnit praxi environmentální výchovy? Na tyto otázky se nyní pokusíme zaměřit.

\section{Teorie informace a předmět environmentální výchovy}

Ústřední místo $v$ informační vědě zaujímá samotný problém podstaty informace. Tento dnes nesmírně frekventovaný pojem se začal používat ve středověké filozofii ve smyslu "vnitřní utváření". Podle Tomáše Akvinského se člověk skládal z jednoty mezi pasivní látkou a aktivní duší, která informuje, čili dává formu, utváří hmotu. Výsledkem této informace pak měla být citlivá a inteligentní bytost. Pozdější autoři chápali informaci jako zprostředkovatele mezi myslí a objekty, tedy to, co umožňuje mysli, aby uchopila tvar a podstatu objektu (Capurro, 2000).

Podle Jana Patočky (Patočka, 1996) je informaci možno chápat jako „universalia in rebus nebo post res", tedy obecninu existující bud' jako princip formující realitu či jako princip v realitě nacházený. Význam "informace" podle Patočky souvisí s pojmem "struktura". Přestože Patočka tyto úvahy již dále nerozvádí, otázka in rebus či post res vede $v$ praxi $k$ velmi rozdílným výkladům světa. Pokud bychom chápali informaci ve smyslu in rebus, znamenalo by to, že jej používáme jako obecný pojem pro vyjádření struktury určitého fenoménu reality. Každý fenomén je nějak „uspořádán" a obsahuje tedy určitou sumu informací, které mohou být objevovány a předávány.

Informace chápaná jako post res naopak vyjadřuje strukturu toho, jak daný fenomén interpretujeme. Když spolu komunikujeme, předáváme si určité výklady světa, které konfrontujeme s horizontem našeho partnera v dialogu.

Raffael Capurro, Peter Fleissner a Wolfgang Hofkirchner (Capurro, 2000) toto téma rozvádí na konkrétním příkladě: mluvíme-li o informacích obsažených například v e-mailové zprávě a o informacích obsažených v našem genetickém kódu, je použití stejného pojmu pro dvě tak rozdílné entity pouhou konvencí, nebo vypovídá o fenoménu společném pro oba jevy? Je podstata toho, co komunikujeme při e-mailové korespondenci či při buněčném dělení stejná, podobná či zcela odlišná?

Šmajs například rozlišuje mezi tzv. strukturální (genetickou) a sémantickou (epigenetickou) a informací (2000). Zatímco první vyjadřuje strukturu fyzického světa, 
druhá odkazuje $\mathrm{k}$ jeho interpretaci $v$ jazyce. Jiné teorie chápou informaci jako matematickou zákonitost, tedy jako určitou platónskou ideu. V tomto smyslu je informace spojována sentropií, respektive je chápána jako negentropie, míra určitosti. Pozoruhodným zpưsobem se zrcadlí v Leibnizově přesvědčení, že každou rozumově uchopitelnou pravdu je možné spočítat a matematicky modelovat...

Zmíněný Peter Fleissner $v$ diskusi se svými kolegy obhajuje pojetí informace in rebus. Podle něj se informace objevuje jako jistý stav hmoty, ale není hmotou samotnou, má určité materiální aspekty, ale má i svou symbolickou rovinu. Hmota a informace jsou tak dvě různé, byt́ související ontologické kategorie.

Třetí z diskutérů, Wolfgang Hofkircher ještě více snižuje rozdíl mezi hmotou a informací. Podle něho informace pochází z hmoty a začíná být generována poté, co hmota přesáhne hranice určenosti a začne se sama organizovat. Informace je tedy svázána se sebeorganizující se hmotou, se životem. To podle Hofkirchera odpovídá i klasické Batesonově teorii informace jako rozdílu, který dělá rozdíl: v sebeorganizujících se procesech se objevuje rozdíl mezi vstupem a výstupem, podněty z okolí jsou brány jako stimul k určité změně - rozdílu.

Naopak Raffael Capurro či u nás Michal Růžička (1993) nechápou informaci jako formu hmoty ani energie. Capurro poukazuje na to, že pokud by informace byla vázána na hmotu, znamenalo by to, že bytí může být digitalizováno: popsáno pomocí nul a jedniček. Podle Rưžičky je informace vždy součástí symbolického světa, je závislá na horizontu daného času, situace, co pro jednoho informací je, pro jiného není. Neexistuje v krystalické, předmětné podobě, ale vždy pouze jako přívlastek bez vlastního obsahu.

Co tedy jsou ony "informace”, které v environmentální výchově předáváme? V environmentální výchově jako bychom pracovali jak s informací in rebus, tak s informací post res. Ve většině programů se zabýváme informací jako symbolickou reprezentací struktur reálného světa. Reprezentací, kterou si předáváme a tak spoluutváříme a přetváříme $v$ procesu komunikačních interakcí.

Př́kladem mohou být simulační hry. V jejich průběhu i závěrečném rozboru vytváříme určité symbolické interpretace světa. Interpretace, které nám umožňují náhled a porozumění studovanému fenoménu, ve své podstatě jsou ale vždy zjednodušené a zkreslené.

Zejména v outdoorových aktivitách ale roste význam druhého pojetí informace jako struktury samotných fenoménů reality. Reality, ke které se můžeme přibližit třeba při tiché chvíli o samotě $v$ lese, nebo při programech zaměřených na bezprostřední smyslový kontakt s prírodou: magické místo, sbírání vưní, kreslení zvuků. ${ }^{1}$

Simulační hry na jedné straně a hry na smyslový kontakt s přírodou na straně druhé tak reprezentují dvě roviny "informace”, se kterými v environmentální výchově pracujeme. Současně je zajímavé si uvědomit, že obě tyto roviny nejsou zcela oddělené: v simulačních hrách sice pracujeme se symbolickou informací, ale směřujeme s ní k uchopení reálných fenoménů. Zkušenosti z magického místa či aktivit na otevírání smyslů zase reflektujeme a tak převádíme do symbolické roviny. Bez vztahování k reálnému by se simulační hry

\footnotetext{
${ }^{1}$ Realita jako taková je ale vždy nedosažitelná a i tehdy, pokud jí vnímáme s maximálním potlačením jazykové reflexe nás od ní odděluje způsob, jakým smyslově vnímáme a následně zpracováváme počitky. V pravém slova smyslu se proto ke "strukturálním" informacím nedostaneme. Přesto cítíme, že při prímém kontaktu s prírodou máme k realitě jaksi blíž, než když si o ní čteme či vyprávíme.

${ }^{2}$ Magické místo je aktivita používaná v programech výchovy o Zemi. Děti si najdou v okolí střediska místo $v$ př́rodě, kde nebudou rušeni ostatními a které je nějak přitahuje. $V$ rámci programu se na Místo pravidelně vracejí, někdy $s$ doprovodnými úkoly. Na svém magickém místě je každý sám. Komunikujeme zde sami se sebou... a snad i s tím, co k nám přichází ze světa, do kterého jsme ponořeni. Rozumíme beze slov...
} 
staly čirým simulakrem a ztratily by legitimitu výukového nástroje, bez symbolické interpretace by zkušenost kontaktu s př́rodou nemohla být zpracována a využita pro formování horizontu studentů.

\section{Teorie komunikace a forma environmentální výchovy}

Základem pojmu "komunikace" je sdílení, v užším smyslu sdílení či předávání informací. Protože se, jak jsme viděli, jednotlivá pojetí informace od sebe značně liší, existují i různá pojetí toho, jak komunikaci rozumět.

Teorie, které mají své východisko v matematických modelech informace, chápou komunikaci jako určité mechanistické předávání „balíku" zprávy informačním kanálem mezi přijímačem a vysílačem. Vysílač nejprve vyšle informaci a poté čeká na odezvu přijímače. Ta se pro něj stává zpětnou vazbou, na jejímž základě původní informaci potvrdí či opraví.

Toto pojetí odpovídá mnoha běžně rozšířeným stylům učení, včetně mnohých programů environmentální výchovy. Podívejme se například na program Cesta do pravěku Centra ekologické výchovy Pálava (Křǐž, 2007). V Aktivitě 1 nejprve učitel ukáže dětem na barevném plátnu základní mezníky vývoje planety Země. Potom děti umístujú obrázky zvířat do správných etap. V závěru učitel zkontroluje, zda se jim to povedlo a připomene, jak probíhala evoluce. Aktivita se řídí schématem „informace - asimilace - kontrola", přičemž asimilační fáze zde hraje roli zpětnovazební reakce přijímače - žáků.

Model IAA (informace - asimilace - aplikace) používaný v metodice výchovy o Zemi odpovídá $v$ zásadě stejnému komunikačnímu modelu. Děti se nejprve dozvědí probíraný koncept (informace), pak si jej přiblíží ilustrační aktivitou (asimilace) a nakonec jej aplikují do navazujícího úkolu. Fáze informace a asimilace zde odpovídají vyslání zprávy vysílačem ( $v$ tomto př́padě je médiem přenášejícím zprávu i samotná aktivita), aplikační fáze představuje zpětnovazebnou smyčku směrem od př́ijemců.

Oproti tomu, informační teorie vycházející z fenomenologie a hermeneutiky zdůrazňují význam kontextu a horizontu v komunikačních situacích (Capurro, 2000; Růžicka, 1993). Kontext je zde symbolicky vyjádřen jako "horizont". Informace je vyjádřením struktury horizontu jednoho a současně výzva pro horizont druhého partnera v dialogu. "Informovat" podle Rưžičky neznamená „předat informace”, ale změnit partnerův horizont. Komunikace proto není aktem „přenosu" informací (transmise), ale změn horizontů (transformace).

Toto pojetí nachází $v$ pedagogické teorii a $v$ psychologii svůj odraz $v$ tzv. konstruktivistické pedagogice. Ta usiluje o takovou metodiku učení, která by pomáhala dětem aktivně si budovat svůj horizont. $\mathrm{V}$ tom vychází jak z Piagetovy teorie poznání, tak i z poznatků kognitivních věd. Fosnotová a Perry přirovnávají proces přerodu složitých systémů na kvalitativně odlišné systémy vyvolaný impulsem na jejich kritickém (bifurkačním) ${ }^{3}$ bodě i samotný fenomén „vyvstávání" nového řádu s procesem zpochybnění určitého prekonceptu (horizontu) na základě jeho konfrontace s novými informacemi, vyvoláním následné pojmové nestability a konečně vynořením nové interpretace zkoumaného fenoménu (Fosnot, Perry, 2005).

\footnotetext{
3 V teorii systémů se jako „bifurkační bod" označuje situace, ve které se určitý otevřený systém nachází v takovém stádiu nestability, že se před ním otevírají dvě naprosto rozdílné a nepredikovatelné cesty dalšího vývoje. Problematikou se zabýval např. I. Prigogin, v nedávné době např. také F. Capra. Použití pojmu v kontextu teorie učení naznačuje nepredikovatelnost nové interpretace fenoménu, která vyvstane po zpochybnění a "pádu" jeho předchozího výkladu.
} 
Konstruktivistické metodiky proto pracují s modely učení umožňujícími zmapovat, zpochybnit a přebudovat svůj horizont.

Cyklus učení (Learning cycle model) zformulovaný v šedesátých letech Karplusem a Atkinem dělí výuku do tři hlavních fází: samostatný průzkum studovaného fenoménu, ve kterém studenti samostatně vytváří hypotézy a otázky; představení konceptu, ve kterém učitel vede žáky k nalezení odpovědí; a aplikace, $v$ rámci které žáci přenáší nové poznatky do další práce (Brooks, Brooks, 1999).

Vrátíme-li se k programu Cesta do pravěku, nacházíme určitou odezvu tohoto modelu v Aktivitě 2. Zde děti dostanou skládačku z koster pravěkých zvířat, které mají složit podle zadaných obrázků. V literatuře pak dohledávají další informace o svém zvířeti, aby je pak mohli prezentovat na „paleontologické konferenci”. Po ukončení konference následují kontrolní otázky na závěr.

Z hlediska komunikačních schémat aktivita odpovídá této sekvenci: motivace k přijetí nových informací - vyslání nových informací "vysílačem" prostřednictvím zadaného textu - přijetí informací a jejich zpětnovazebné potvrzení př́jemcem formou prezentace.

Slabinou aktivity je, že nevyužívá motivačního potenciálu "skládačkové" aktivity ke generování hypotéz, jejichž zodpovídání by dětem umožnilo dojít k hlubšímu porozumění tématu. Problém je pravděpodobně v nedostatečné vazbě mezi cílem celého programu ("uvědomění si, že život se vyvíjí, že se postupně měnil do dnešní podoby a my bychom $\mathrm{k}$ tomuto procesu měli mít patřičnou úctu a ovlivňovat vývoj druhů jen pozitivně" (Kř́žz, 2007) a cílem aktivity, která směřuje pravděpodobně k rozšíření znalostí o vyhynulých druzích. Aktivitu by patrně stačilo jen lehce pozměnit, aby lépe odpovídala modelovému cyklu učení. Připust'me, že by děti v první fázi dostaly kromě hromádky skládačkových dílků různých pravěkých zvířat také charakteristiku krajiny a podmínek, odpovídající některému z pravěkých období. Jejich úkolem by bylo sestavit takového živočicha, který by $v$ daném prostředí obstál. Děti by byly vedeny úkolem či doplňujícími otázkami k formulaci hypotéz: mělo by $v$ těchto podmínkách šanci přežít spíše velké zvíře či malé? Mořské či suchozemské? Má-li to být dravec, jaké by měl mít tělo a hlavu? K zodpovězení by pracovaly s publikacemi, které by měly k dispozici. $\mathrm{Na}$ konci by porovnaly svého živočicha s pravděpodobným vzhledem zvířat stejného období a připravily by si pro ostatní prezentaci, kde by své zvíře představily, porovnaly s doloženými druhy a vysvětlily jeho stavbu těla a další znaky ve vztahu k tehdejším prrírodním podmínkám, vysvětlily, proč by nemohl žít v jiných podmínkách (obdobích) atd.

Komunikační schéma by nyní vypadalo takto: motivace k vyjádření a zpochybnění svého horizontu - konfrontace s novými poznatky a následná modifikace prvotního konceptu - prezentace nově získaného náhledu.

Tzv. třífázový model učení je používán v konstruktivistickém přístupu „čtením a psaním ke kritickému myšlení". Učitel v něm nejprve otevírá prostor pro evokaci toho, co žáci o tématu vědí, poté je konfrontuje s novými informacemi (fáze hledání nového významu) a nakonec dává prostor pro reflexi nového porozumění. $V$ prípadě programu Cesta do pravěku takové schéma chybí. V Aktivitě 1 jsou žáci informováni učitelem o vývoji planety a poté to asimilují formou aktivity. V Aktivitě 2 skládají zvírátka a učí se o nich nové informace. V Aktivitě 3 skládají do správného pořadí kartičky s názvy geologických období. V nejvíce konstruktivistické Aktivitě 4 děti přemýšlí, jak se na Pálavu mohly dostat příslušné zkameněliny. V Aktivitě 5 vyrábí sádrové odlitky zkamenělin, které si odnáší domů na památku.

Pokud bychom analyzovali z hlediska komunikačních modelů program jako celek, najdeme v něm opakované schéma "Informování - asimilace - kontrola ( $A 1)$ - motivace k dalšímu př́jmu informací - informace - kontrola (A2) - Aplikace a kontrola (A3) asimilace/hledání nového významu (A4) - opakování, kontrola (A5). 
Připustíme, že bychom program jako celek chtěli zpracovat podle tříázového modelu. Mají-li si děti uvědomit fenomén vývoje života na Zemi, měli bychom zahájit program aktivitou, ve které by děti mohly vyjádřit své stávající porozumění problematice. To bude závislé i na věku žáků a kontextu jejich dosavadní výuky, není proto štastné, že program je určen pro širokou skupinu děti od třetí do deváté třídy. Evokace pro menší děti by mohla vypadat třeba tak, že by lektor formou vhodné motivační scénky děti vzal do "stroje času", řekněme 100 miliónů let zpátky. Před cestou by se ale měly dobře připravit - např́klad se ve skupině dohodnout na seznamu věcí, které by si měly vzít s sebou (anebo si je prímo vybrat ze skladu, jsme-li na terénní základně). Při výběru by sledovaly určitá kritéria: například teplotu, jestli očekávají prales či bažiny, dravá zvířata nebo krotké býložravce... Svoji volbu by měly dobře zdůvodnit. $V$ této fázi by tedy děti nenásilně uvedly, co o době vědí a současně by konfrontovaly svůj horizont se spolužáky.

Ve druhé fázi by mělo dojít na konfrontaci s novými poznatky. Do ní by mohly být formou dobrodružství zabudovány mnohé prvky z analyzovaného programu: např́klad Aktivita 2 zpracovaná modelem cyklu učení, Aktivita 4, Aktivita 5 atd. Abychom dosáhli druhé části deklarovaných cílů programu (, $[\ldots]$ a my bychom $\mathrm{k}$ tomuto procesu měli mít patřičnou úctu a ovlivňovat vývoj druhů jen pozitivně" (Křǐ̌̌, 2007)), bylo by dobré promyslet ještě zařazení další aktivity, která by takovému formování úcty napomohla (např. př́běh posledního tyranosaura pojatý jako dramatický boj sympatického hrdiny o přežití atd.).

Na konci programu by neměla chybět reflexe. Zde se nabízí zpracování vědecké zprávy o cestě do pravěku, kterou by připravily a prezentovaly jednotlivé týmy.

\section{Vertikální a horizontální, autentická a neautentická komunikace}

Raffael Capurro v eseji o angeletice navrhuje rozlišovat tzv. horizontální a vertikální komunikační mody (2000). Zatímco horizontální komunikační situace jsou ty, kdy komunikující partneři jsou ve vztahu k autoritativnímu výkladu smyslu na stejné úrovni, vertikální komunikace je orientovaná směrem dolů od centra moci. Příkladem vertikálních komunikačních situací jsou nejenom autoritativní výklady reality $v$ totalitních režimech, ale také např. „andělská" poselství, zprávy prezentované jako „hlas Boží". Smyslem vertikální komunikace není sdílet a konfrontovat horizont druhého, ale přimět druhého $\mathrm{k}$ akceptaci určitého horizontu. Vrátíme-li se ke dvojímu chápání informace, vidíme, že horizontální komunikace se odehrává ve světě symbolických (či Šmajsovou terminologií "sémantických") informací, zatímco vertikální je prezentována jako formování symbolického horizontu strukturálními informacemi: výkladu světa tím, jaký svět (z pohledu autority) je. ${ }^{4}$ Problémem vertikální komunikační strategie je nedostatek legitimity. Symbolická komunikace je víceznačná a naše poznání světa je vždy pouhou nedokonalou interpretací. Snaha mnohých středisek ekologické výchovy o maximální přesnost a správnost výukových programů je tak ve své podstatě zpochybněna nepřesností a omezenou správností našeho poznání jako takového. ${ }^{5}$ Problémem

\footnotetext{
${ }^{4}$ V environmentální výchově představuje vertikální modus komunikace se studenty velké pokušení pro každého učitele. Tolik bychom chtěli, aby žáci byli soucitní s př́rodou, uvědomovali si hodnotu každého života, věděli, že „mít je méně než být...". Tolik by se chtělo prostě jen říct: takhle věci jsou, takové je berte...

${ }^{5}$ Ilustruji historkou: jedno ze středisek ekologické výchovy se kterými spolupracuji, dává velký důraz na odbornou a faktickou správnost svých programů. Po prezentaci programu na pozorování prírody na jedné z dílen pro širší veřejnost jsem se o programu bavil s bioložkou z jiného střediska. Podle ní obsahoval program několik odborných nepřesností, pocházejících ze starších publikací. „Dříve se to tak učilo, ale dnes už ne." Nepochybuji o tom, že i současné názory kritické bioložky za deset let projdou proměnou. Př́běh ilustruje obecný problém: naše poznání světa nikdy nebude dokonalé a proto mưžeme být přesní jen ve vztahu k určitému diskursu.
} 
horizontální komunikace na straně druhé je krize autenticity. Bez vazby k autoritě hrozí rozpad vazby mezi znakem a objektem a určitá virtualizace světa, kde "všechno je možné, ale nic není reálné". Propad současné informační společnosti - společnosti mocně ovlivňované horizontálními informačními technologiemi (jako jsou mobilní telefony či internet) do určité hyperreality, ve které se simulované jeví reálněji, než realita samotná, popisuje ve svých esejích J. Baudrillard. (2001) Bez vazby k autoritě je stejně legitimní tvrzení "každé zvíře má svoji vlastní hodnotu" jako "každé zvíře má hodnotu jenom pro mě na talíri", respektive obě tvrzení jsou stejně nelegitimní.

Máme vůbec právo tvrdit, že první výrok je pravdivý a druhý nikoliv? Zde se otevírá prostor pro rozšířené chápání "autority”, jako zdroje legitimity určitých výpovědí o světě a současně specifického aktéra komunikace. Podle Heideggera nikoliv my, ale „řeč mluví" (Heidegger, 1993). Básníkovy výpovědi o světě nejsou svévolnými interpretacemi nepoznatelné reality, ale autentickou formulací prožitku bytí, kterému se otevírá. Autentický prožitek bytí, otevření se nepodmíněné paradigmaty společenských a přírodních věd se zde stává autoritou legitimizující výpověd' a současně i jistým aktérem komunikace.

Prostor pro vertikální komunikaci proto v environmentální výchově zůstává ve zprostředkování přímého kontaktu s bytím, se světem tak jak je sám o sobě, bez našich výkladů a interpretací. Takový kontakt je přitom zásadní nejenom pro formování našich postojů ke světu, ale i pro porozumění sobě samotným.

Jak ukázal Martin Heidegger, bez vztahu k bytí člověk ztrácí sám sebe a jeho komunikace s ostatními se stává pouhými „řečmi", utrácením času bez vztahu k sebenalézání a sebenaplňování (1996). Mezi autentickou komunikací a nalezením vlastního já je jasná souvislost. Člověk, který se dokáže otevřít světu a přijmout jeho nezprostředkovaná "poselství" je více sám sebou, jeho názory, jakkoliv i ony jsou jen interpretací, jsou výrazem autentického hledání sebe a svého místa na světě.

Jestliže podle Heideggera autenticky být znamená otevřít se plně bytí, Patočka (1995) autentické bytí chápal jako proces naplňování tří "pohybư" - zakořeňování, sebeprodlužování a hledání pravdy - podle Jany Dlouhé „pohyb průlomu” (Dlouhá, 2006). Autentický člověk se snaží najít své místo na světě, vytváří svoji sít vztahư a čelí mezním situacím, které jej postihují. To odpovídá jedné z klíčových dimenzí environmentální výchovy - formování vztahu k místu, jeho historii, geniu loci (Orr, 1994; Capra, 2005).

Ve druhém pohybu se autentický člověk aktivně vztahuje ke světu, promítá do něj své představy a čelí pokušení dogmatizmu či konzumerismu. V environmentální výchově tento pohyb odpovídá dưrazu na občanskou participaci, řešení komunitních problémů, rozvíjení akčních kompetencí studentů (Hammond, 1996-7; McKeowyn, 2002).

Oba předchozí pohyby spojuje Patočka kritickým zpochybňováním, dialogem, hledáním v sokratovském smyslu, kdy sice na pravdu nikdy úplně nedosáhneme, ale přesto se k ní stále snažíme přiblížit. Dialog, dialogické učení, na jehož počátku právě Sokrates stál, je tak vyjádřením jak našich stálých pochybností, tak autenticity hledajícího člověka. ${ }^{6}$ Svým způsobem je tedy smyslem environmentální výchovy být průvodcem, partnerem $v$ dialogu, $v$ procesu hledání vlastní autenticity. Takové pojetí environmentální výchově vrací její legitimitu: není ničím jiným, než odvěkým společným hledáním místa, které zaujmeme na Zemi.

\footnotetext{
${ }^{6}$ Myslím, že důležitým aspektem třetího pohybu ve vztahu k environmentální výchově je poctivost hledání. K té patří jak ochota "otevř́i se bytî", tak snaha o kritické porozumění, porovnání zdrojů, studium, diskuze. Jestliže pozitivisticky laděná ekologická výchova s důrazem na fakta a odbornou přesnost představuje jeden poněkud problematický pól environmentální výchovy, pohybuje se mysticizující hlubinně ekologická výchova se svými rituály a meditacemi na opačném extrému. Zlatá střední cesta by měla uvážlivě kombinovat rozum s emocemi, porozumění s postoji, levou hemisféru s pravou.
} 
To klade veliké nároky na lektory, kteří by měli být méně mentory a více průvodci, méně jistí a více hledající. Na druhé straně takové pojetí z lektorů i část tíhy odnímá: nejsou nositeli pravdy, ale poutníky na stejné cestě, jako jejich mladší společníci.

\section{Závěr}

Informační věda jakožto věda o celém procesu informace se dotýká otázek, které jsou zásadní i pro environmentální výchovu. Diskuse o podstatě informace jako fenoménu strukturujícího reálný svět či jeho symbolické interpretace nám umožňuje porozumět tomu, že i v programech environmentální výchovy pracujeme jak s reálným světem, tak s jeho symbolickým vyjádřením a že tak jako simulační hry nesmí ztrácet kontakt $\mathrm{s}$ realitou, tak i u prímého kontaktu s prírodou musíme ponechat prostor a volnost pro jeho symbolické zpracování.

Rozdílné pohledy na podstatu komunikace se odráži i do různých modelů výuky. Analýza výukových programů jako sledu komunikačních situací nám umožňuje porovnávat programy vycházející z matematicko-pozitivistického nebo fenomenologickokonstruktivistického pojetí.

Problém vertikality a horizontality komunikace otevírá problém legitimity a smyslu environmentální výchovy. Jeho řešení se může nacházet $v$ trojúhelníku environmentální výchova - komunikace - autenticita.

\section{Literatura}

- Baudrillard, J. (2001). Dokonalý zločin. Olomouc: Periplum.

- Brooks, J. G., \& Brooks, M. G. (1999). In search of understanding : The case for constructivist classroom. Alexandria: Association for Supervision and Curriculum Development.

- $\quad$ Capra, F. (2005) Speaking Nature's Language : Principles of Sustainability. In M. K. Stone \& Z. Barlow (Eds.), Ecological Literacy : Educating Our Children for a Sustainable World. San Francisco: Sierra Club Books.

- Capurro, R. . Epistemology and information science [online]. [Poslední aktualizace 2000-0527]. .

- Capurro, R., Fleissner, P., \& Hofkirchner, W. . Is a Unified Theory of Information Feasable? : A Trialogue [online]. [Poslední aktualizace 2000-05-29]. . Retrieved from http://www.capurro.de/trialog.htm

- Capurro, R. . On the genealogy of information [online]. [Poslední aktualizace 2000-05-27]. . Retrieved from http://www.capurro.de/moral.htm

- Capurro, R. . What is Angeletics? [online]. [Poslední aktualizace 2000-09-18]. .

- Capurro, R. (2001). Ethical Challenge of the Information Society in the 21st Century [online]. [Poslední aktualizace 2001-02-17]. .

- Capurro, R. (2001). Moral Issues in Information Science [online]. [Poslední aktualizace 200105-12]. . Retrieved from http://www.capurro.de/moral.htm

- Currás, E. (1996). Pojem informace v kontextu vědecké integrace. Acta Bibliotecalis et Informatica, 
- Dlouhá, J. (2006). Zkušenost prírody - jaká je a co ve výchově znamená?. Envigogika, 1(1), 2007-8. Retrieved from http://www.envigogika.cuni.cz/index.php/Envigogika/article/view/3

- FOSNOT, Catherine Twomey, PERRY, Randall Stewart, (2005) Constructivism : a psychological theory of learning. In C. T. Fosnot (Ed.), Constructivism : Theory, Perspectives and Practice. New York: Columbia University.

- Hammond, W. F. . Education for Action : A framework for thinking about the place of action in environmental education. Green Trachet : Education for Planet Earth, 1996-7, 6-14.

- $\quad$ Heidegger, M. (1996). Bytí a čas (Being and Time). Praha.

- Básnicky bydlí člověk.(Vorträge und Aufsätze) (1993) Řeč. In Praha: OIKOYMENH.

- Iran-nejad, A. (1995). Constructivism as substitute for memorization in learning : Meaning is created by learner. Education. Fall, 116(1), 16.

- McKEOWYN, R. (2002). Education for Sustainable Development Toolkit [online]. : University of Tennessee.

- Kř́ž, M. (2007). Cesta do pravěku. Bedrník, 5(1), 22-1381.

- Matre, S. v. (1999). Earth Education : A new beginning. Greenville: The Institut for Earth Education.

- ORR David W, (1994). Earth in Mind : On Education, Environment, and the Human Prospect. Washington: Island Press.

- Patočka, J. (1996) Filosofie a společenský problém informace. In Acta Bibliotecalis et Informatica. Opava: Slezská univerzita.

- Patočka, J. (1995). Tělo, společenství, jazyk, svět. Praha: OIKOYMENH.

- Růžička, M. (1993). Informace a dobro. Praha: Ježek.

- Šmajs, J. . Drama evoluce : Fragment evoluční ontologie. Praha: Hynek.

\section{Recenzní posudky (slovní hodnocení příspěvku)}

\section{Recenzent 1:}

Jan Sokol - Fakulta humanitních studií UK

„Článek se pokouší o důležité téma, přináší však přiliš mnoho nesouvisejících pohledů a názorů. Autorovy pokusy o vyjasnění pojmu: ,informace' jej nakonec nevysvětlují: jde o cosi (metafyzicky) konkrétního, co nějak případně pưsobí, nebo pouhý vztah? Je ,informací např. text, anebo to, že se někdo nechal ,informovat'? Stručně řečeno: je kniha, kterou nikdo nečte nebo jí nerozumí, informace? Dokud se tohle jasně nerozliší, nedá se o ní nic rozumného říct. Patočkův příležitostný článek s rozlišením realizmu a nominalizmu není dobré východisko.

Dále: co znamená, že se někde ,pracuje přímo s realitou'? Bud' že se třeba pije voda, anebo se o něčem mluví. Ale v obou případech je to silně zprostředkované, např. jazykem a pojmy (i vodu musí člověk najít a poznat). Proč je smyslové ,přibližování k realitě jaksi autentičtější, lepší? Informují nás smysly o něčem, co se v procesu interpretace ztrácí? To jsou skryté, nevysvětlené předpoklady autorových závěrů, které se však svou prací pokouší doložit. 
Shrnuto: chybí otázka (proč to říká? komu?) a hypotéza (jak to je?). ,Pohled informační vědy' nic moc neslibuje: to je její věc, my bychom chtěli vědět, co říká nám, čím nás chce informovat $v$ naší věci. Hlavní přednost je spíš tušené než vyjádřené téma: má informační věda co říci $\mathrm{k}$ ekologické výchově? Vady příspěvku: neuspořádané, rưzné názory bez souvislostí."

\section{Recenzent 2:}

\section{Michal Lorenz - Filozofická fakulta MU}

„Autor v textu naplňuje téma práce propojením informačních a komunikačních teorií s programy environmentální výchovy. Za největší pozitiva textu považuji úpravu stávajících programů dle konstruktivistické pedagogiky, myšlenku nezbytného doplňování symbolických a strukturálních informací ve všech environmentálně-vzdělávacích aktivitách. Problematické zůstává chybějící vymezení rozdílu mezi informacemi (případem universálií, objektivních struktur) a poznáním (subjektivním procesem) při outdoorových aktivitách a smyslovém kontaktu s př́rodou. Text je logicky strukturovaný, závěry jasné. Text je zajímavý, doporučuji jej k publikování."

\section{Recenzent 3:}

\section{Gabriela Kustová - Pedagogická fakulta UK}

„Environmentální výchova, jeden z moderních pojmů v současné pedagogice, si klade poměrně ambiciózní cíle: pochopení složitosti a provázanosti člověka s životním prostředím tak, aby byl takto veden $\mathrm{k}$ jeho aktivní ochraně a citlivému př́stupu. $\mathrm{V}$ tomto pojetí je nutno člověka považovat za součást přírody, za přírodu novou, která tu stávající dotváŕí a svým dílem překračuje, aniž by zůstal od ní jakkoli oddělen. Z tohoto důvodu je velmi důležitá otázka metodiky a cílů environmentální výchovy, jimiž se konkrétně tento článek zabývá z pohledu informačních a komunikačních technologií.

Ačkoli se na první pohled zdá, že informační a komunikační technologie mají s environmentální výchovou pramálo společného, lze přesto mezi nimi najít styčné body a paralely. Základním pojmem se stává "informace" v Aristotelsko-Tomistickém slova smyslu, jakožto proces vnitřního utváření skládajícího se ze dvou složek, z nichž jedna je aktivní, formující, a druhá pasivní, hmotná. Tento pojem je proto dále interpretován ve dvou rovinách: $v$ rovině faktické, $a v$ rovině sémantické (symbolické). Proto nelze přistupovat k informaci jako k „pouhému" věcnému sdělení, ale je nutno přihlédnout k jejímu symbolickému významu, který je situační a vyžaduje interpretaci v kontextu (horizontu). V environmentální výchově je kladen stejný dưraz na obě dvě roviny, tato provázanost a neoddělitelnost je základní metodou předávání informací. Jen $v$ této souvztažnosti obou rovin Ize dosáhnout celistvosti a uchopit tak informaci v celém rozsahu svého významu, jen tak má proces vzdělávání smysl.

S informací je možné pracovat ve významu in rebus (princip, který realitu formuje), či post res (princip, který je $\mathrm{v}$ realitě nacházen). Environmentální výchova přistupuje $\mathrm{k}$ informaci $\mathrm{v}$ obou slova smyslech; nejprve jako $\mathrm{k}$ aktivní struktuře, která vyžaduje zejména symbolickou rovinu výkladu (např. simulační hry), dále pak je třeba pracovat s druhým pojetím informace jakožto uspořádáním fenoménů reality (přímý kontakt s prírodou).

Smysluplná komunikace je taková, při níž dochází ke změně horizontu všech jejích účastníků. Není jen pouhým sdělením, obsahuje obě roviny výkladu, je formující, podnětná. Otázkou je legitimita environmentální výchovy v kontextu horizontální a vertikální, autentické a neautentické komunikace. Vertikální komunikace nekonfrontuje horizont druhého, pouze podsouvá ten svůj, čímž přichází o rovinu symbolickou. Komunikace horizontální se vlivem informačních technologií (mobilní telefony, internet) potýká s krizí autenticity, když nabízí simulaci, která se zdá reálnější než realita samotná, přesto jí není. Neautentická komunikace zabraňuje prožitku plnosti bytí. Environmentální 
výchova má svůj smysl v hledání kompromisu mezi těmito metodami; být partnerem $\checkmark$ dialogu, který aktivně posouvá horizont a zároveň pomáhat všem účastníkưm nalézat vlastní autenticitu.

Článek je zajímavým a originálním vhledem do metod environmentální výchovy. Operuje s pojmem "informace" v rovině pozitivistické i fenomenologické, kriticky zpracovává nejnovější poznatky, hledá a nachází legitimitu pro otázky, které si klade. Za př́nosné považuji zejména zamyšlení nad smyslem a obsahem komunikace $v$ kontextu informačních a komunikačních technologií s využitím těchto poznatků k hledání autenticity a pravdy nejen $v$ environmentální výchově.

Myslím si, že některé body $v$ textu by si zasloužily podrobnější komentář; je mi jasné, že na tomto prostoru to není úplně možné, ale text by působil výstižněji, návaznosti by se více zjasnily a text by byl čtivější. $V$ pasážích, kde autor uvádí několik teorií interpretace určitého pojmu, postrádám konečný resultát, tedy to, k čemu se on sám přiklání a proč. Celkový výraz textu by pưsobil o něco lépe také pečlivějším systémem odkazů a citací." 
Časopis Envigogika vydává Centrum pro otázky životního prostředí UK. Vývoj časopisu je podpořen projektem OP VK Mezioborová sít udržitelného rozvoje.

Více najdete na internetových stránkách projektu mosur.czp.cuni.cz
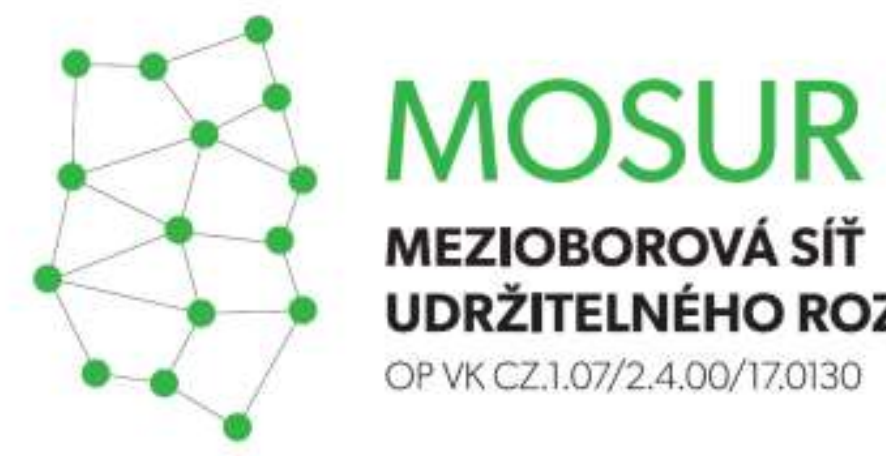

\section{MEZIOBOROVÁ SÍT} UDRŽITELNÉHO ROZVOJE

OP VK CZ.1.07/2.4.00/17.0130
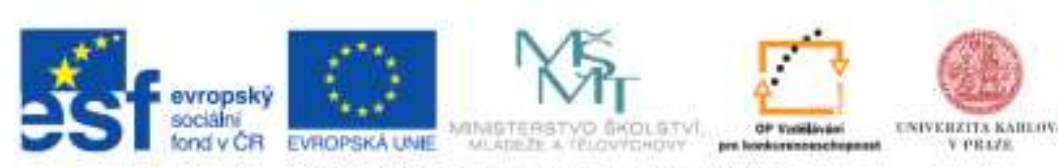

INVESTICE DO ROZVOJE VZDELAVANI 